\author{
PRZEELLID SEJMOWY \\ nr 1(156)/2020, s. 195-204; https://doi.org/10.31268/PS.2020.11
}

\title{
GLOSY
}

\section{Glosa do wyroku Sądu Najwyższego z 28 kwietnia 2010 r. sygn. akt III CSK 143/09*}

W glosowanym wyroku Sąd Najwyższy jednoznacznie stwierdził, że do roszczenia z tytułu zachowku nie może być stosowany w drodze analogii art. $445 \S 3$ k.c. Próba uzupełnienia art. 1002 k.c. treścią normatywną art. $445 \S 3$ k.c. jest całkowicie chybiona przede wszystkim ze względu na zróżnicowany charakter prawny obydwu roszczeń, ale także odmienny cel i ratio legis. Przyjęte w prawie polskim rozwiązanie normatywne w przedmiocie dziedziczności roszczenia z tytułu zachowku (art. 1002 k.c.) budzi uzasadnione kontrowersje. Doniosłość problemu potwierdzają formułowane w doktrynie i w orzecznictwie wątpliwości co do jego konstytucyjności. Podmiotowe ograniczenia co do nabycia roszczenia o zachowek w drodze dziedziczenia mogą bowiem prowadzić do nierównego traktowania spadkobierców w zależności od wybranego przez spadkodawcę sposobu pokrycia zachowku. Wprowadzenie warunków dziedziczenia tej wierzytelności w kontekście braku ograniczeń odnośnie do przelewu wierzytelności z tytułu zachowku jest nielogiczne i prowadzi do oczywistej niespójności systemowej.

SŁowa KLUCzowe: dziedziczenie, roszczenie z tytułu zachowku, roszczenie o zadośćuczynienie pieniężne za doznaną krzywdę

\section{Commentary to the judgment of the Supreme Court of 28 April 2010, ref. no. III CSK 143/09}

\begin{abstract}
According to the judgement of the Supreme Court, Article 445(3) of the Civil Code cannot be applied by way of analogy to the claim for legitim. An attempt to supplement Article 1002 of the Civil Code with the normative contents of Article 445(3) of the Civil Code failed completely mostly because of diverse legal character of both legitims as well as different purpose and ratio legis. Normative solutions with regard to the heredity of the claim for legitim accepted in Polish law (Article 1002 of the Civil Code) stir up justifiable controversies. The importance of the matter is confirmed with doubts as to its constitutionality formulated both in the doctrine and judicial decisions. Subjective limitations as to acquisition of the claim for legitim by inheritance may result in uneven treatment of heirs depending on the way to pay the legitim the testator has chosen. The introduction of conditions of the inheritance of this claim seems illogical in view of lack of any limitations as to assignment of claims for legitim and leads to obvious systemic inconsistence.
\end{abstract}

KEY wORDS: inheritance, claim for compensation for harms, claim for legitim

\footnotetext{
* Wyrok Sądu Najwyższego z 28 kwietnia 2010 r. (sygn. akt III CSK 143/09), Lex nr 589808.
} 
W glosowanym wyroku Sąd Najwyższy skoncentrował swoją uwagę na problematyce dziedziczenia roszczenia z tytułu zachowku. O jej doniosłości nie trzeba przekonywać, skoro zarówno w doktrynie, jak i w orzecznictwie wyraźnie formułuje się wątpliwości co do konstytucyjności przyjętego w tym zakresie rozwiązania normatywnego (art. 1002 k.c.).

W tezie wyroku SN jednoznacznie stwierdził, że do roszczenia z tytułu zachowku (art. 1002 k.c.) nie może być stosowany w drodze analogii art. $445 \S 3$ k.c. Wyrok zapadł w następującym stanie faktycznym: mająca dwóch synów i znaczny majątek spadkodawczyni uczyniła jedynym spadkobiercą testamentowym Zamek Królewski na Wawelu - Państwowe Zbiory Sztuki w Krakowie. Jednocześnie w testamencie wydziedziczyła jednego z synów. Wydziedziczony syn zmarłej wystąpił z powództwem o zachowek, podnosząc bezpodstawność wydziedziczenia. Sąd Okręgowy w Krakowie w wyroku wstępnym (sygn. akt I C 122/06) uznał roszczenie powoda za słuszne co do zasady. Ustalił, że nie zachodziły okoliczności uzasadniające pozbawienie prawa do zachowku. Przed wydaniem wyroku wstępnego zmarł drugi syn spadkodawczyni. W toku postępowania apelacyjnego strony, mając na uwadze możliwość ugodowego załatwienia sprawy, zgodnie wniosły o zwieszenie postępowania. W zawartej ugodzie strony przyjęły, że powód jest uprawniony do zachowku w wysokości 1 1 2 części wartości udziału spadkowego, który by mu przypadał w dziedziczeniu ustawowym. Pozwany zobowiązał się do zaspokojenia nie tylko roszczenia powoda z tytułu zachowku, ale także roszczenia $\mathrm{z}$ tego samego tytułu przysługującego zmarłemu bratu powoda jako jego spadkobiercy. Niespełna dziesięć miesięcy po zwarciu ugody powód zmarł, a spadkobierca testamentowy, powołując się na wygaśnięcie roszczenia, przestał ugodę wykonywać. Jedyna spadkobierczyni powoda — jego żona — wystąpiła wówczas z wnioskiem o podjęcie zawieszonego postępowania. Sąd podjął postępowanie, stwierdzając istnienie okoliczności, które nie były znane Sądowi Okręgowemu, a także ustalił fakty, które zaistniały już po wydaniu wyroku wstępnego. W postępowaniu apelacyjnym ustalono, że umowami zawartymi w formie aktów notarialnych powód dokonał przelewu wierzytelności z tytułu zachowku w wysokości $7 \mathrm{mln}$ zł na rzecz swoich pełnomocników procesowych, a następnie, już po jego śmierci, dokonano „przelewu zwrotnego" na jego żonę. Sąd Apelacyjny (sygn. akt I ACa 1139/08) zmienił zaskarżony wyrok w ten sposób, że powództwo oddalił. Stwierdził, że z uwagi na to, że żona powoda nie należy do osób uprawnionych do zachowku po jego matce, roszczenie o zachowek wygasło w dniu śmierci powoda i nie może być skutecznie dochodzone. W skardze kasacyjnej powódki głównym zarzutem był zarzut naruszenia art. 1002 k.c. ,,przez niewłaściwe zastosowanie, polegające na uznaniu, że roszczenie o zachowek przechodzi tylko na spadkobierców uprawnionych do zachowku, gdy tymczasem jeszcze za życia powoda strona pozwana uznała na piśmie jego roszczenie, w związku z czym wchodzi ono w skład spadku i jest dziedziczone na zasadach ogólnych, zgodnie z zasadą słuszności oraz celami zachowku, bez ograniczeń podmiotowych przewidzianych w art. 1002 k.c.".

Nie budzi wątpliwości, że podjęta w skardze kasacyjnej próba uzupełnienia art. 1002 k.c. treścią normatywną art. $445 \S 3$ k.c. jest całkowicie chybiona, tak jak 
niczym nieuprawnione jest ogólne stwierdzenie, że ,akt uznania oraz wniesienie powództwa przekształca roszczenia niedziedziczne w prawa należące do spadku”. Wskazane przez SN argumenty przemawiające przeciwko stosowaniu w drodze analogii art. $445 \S 3$ k.c. do roszczenia $\mathrm{z}$ tytułu zachowku w pełni zasługują na aprobatę. Nie mogło w szczególności ujść uwadze Sądu, że roszczenie o zadośćuczynienie pieniężne za doznaną krzywdę i roszczenie z tytułu zachowku mają odmienny charakter prawny. Pierwsze z nich jest roszczeniem osobistym, ściśle związanym z osobą uprawnionego, niemieszczącym się w „formule” praw podlegających dziedziczeniu (art. 922 § 2 k.c.), podczas gdy roszenie o zachowek jest roszczeniem pozbawionym pierwiastka osobo$w_{\text {ego }}{ }^{2}$. Roszczenie o zachowek wynika z prawa do zachowku, które jest osobiste, niezbywalne i niedziedziczne ${ }^{3}$. Nie można bowiem przenieść na inny podmiot swojej „osobistej właściwości, jaką jest przynależność do rodziny i kręgu uprawnionych do zachowku" 4 .

Roszczenie o zadośćuczynienie pieniężne za doznaną krzywdę jest roszczeniem ściśle osobistym, a jednak ustawodawca dopuścił możliwość jego dziedziczenia w określonych warunkach. Poprzez art. $445 \S 3$ k.c. ustawodawca wprowadził wyjątek od zasady zawartej w art. 922 § 2 k.c., wskazując okoliczności, których zaistnienie prowadzi do „przekształcenia" niedziedzicznego co do zasady prawa podmiotowego w prawo wchodzące w skład spadku. Przyjął, że na skutek uznania roszczenia na piśmie czy też wytoczenia powództwa za życia poszkodowanego dochodzi do konkretyzacji roszczenia przez samego poszkodowanego w takim stopniu, „że — odrywając się od jego osoby — może stać się przedmiotem spadkobrania”. Nie bez znaczenia jest także „motyw niezwalniania sprawcy szkody z odpowiedzialności tylko dlatego, że poszkodowany zmarł". Bezspornie odmienny cel towarzyszył ustawodawcy przy wprowadzeniu ograniczeń dziedziczności roszczenia z tytułu zachowku na rzecz najbliższych członków rodziny uprawnionego. Sąd Najwyższy nie znalazł również podstaw do konstruowania analogii do dziedziczności roszczeń alimentacyjnych, które stały się wymagalne za życia uprawnionego i zostały prawomocnie zasądzone na jego rzecz. Roszczenie o zachowek ma bowiem zupełnie, ,inny charakter, jest zbywalne i jako instytucja prawa spadkowego nie może być w żaden sposób kojarzone z roszczeniami alimentacyjnymi, nawet sensu largo". Jego wysokość ,nie zależy od walorów podmiotowych uprawnionego i zobowiązanego ani od jakichkolwiek wartościowań po ich stronie". Zatem o tożsamości aksjologicznej tych dwóch roszczeń, jak wyraźnie podkreślił SN, „nie może być mowy”.

$\mathrm{Na}$ tle opisanego stanu faktycznego ,ujawnił się" z całą mocą niebagatelny problem dziedziczności roszczenia z tytułu zachowku. Niebagatelny, zwłaszcza z powodów

2 Vide uzasadnienie uchwały SN z 20 grudnia 1988 r., sygn. akt III CZP 101/88, OSP 1990, nr 4, poz. 213 oraz uzasadnienie wyroku TK z 25 lipca 2013 r., sygn. akt P 56/11, OTK ZU 2013, 6/A/11; uchwała SN z 25 lutego 1925 r., sygn. akt III Rw 102/25, PPiA 1925, s. 125; orzeczenie SN z 27 maja 1930 r., sygn. akt III. 1 Rw. 2565/29, PPiA 1930, nr 4, s. 429; uchwała siedmiu sędziów SN z 21 października 1931 r., sygn. akt III. Prez. 91/31, OSP 1932, poz. 452.

3 Vide np. P. Księżak, Komentarz do art. 1002, [w:] Kodeks cywilny. Komentarz, t. III, Spadki, red. K. Osajda, Warszawa 2013, teza 1.

${ }^{4}$ P. Księżak, Zachowek w polskim prawie spadkowym, Warszawa 2012, s. 358, s. 358. 
wcześniej wskazanych (wątpliwości co do konstytucyjności art. 1002 k.c.), ale także z uwagi na przyjęty sposób obliczania jego wysokości (zachowek może niekiedy wynosić nawet $2 / 3$ spadku).

Roszczenie o zachowek podlega dziedziczeniu ${ }^{5}$, ale według reguł odbiegających od tych, które zostały wyrażone w art. 922 k.c. ${ }^{6}$ Zgodnie z art. 1002 k.c. roszczenie z tytułu zachowku przechodzi na spadkobiercę osoby uprawnionej do zachowku tylko wtedy, gdy spadkobierca ten należy do osób uprawnionych do zachowku po pierwszym spadkodawcy $^{7}$. W braku spadkobierców uprawnionych do zachowku po pierwszym spadkodawcy, roszczenie z tego tytułu wygaśnie, co oznacza, że „odziedziczą” je spadkobiercy tego pierwszego spadkodawcy. Krąg tych spadkobierców, jak i osób uprawnionych do zachowku pozostanie bez zmian ${ }^{8}$.

Ujęcie polskiego kodeksu cywilnego jest wyjątkowe i nowatorskie ${ }^{9}$. Warto przypomnieć, że w art. 158 dekretu z dnia 8 października 1946 r. — Prawo spadkowe ${ }^{10}$ nie przewidziano żadnych ograniczeń w dziedziczeniu roszczenia z tytułu zachowku. Zgodnie z powołanym unormowaniem prawa spadkobierców koniecznych przechodzą na ich spadkobierców. Prawa te przechodzą według zasad ogólnych na spadkobierców ustawowych, jak i testamentowych ${ }^{11}$. W czasie obowiązywania dekretu z 1946 r. w literaturze podnoszono, że w przypadku braku art. 158 dekretu zachodziłaby wątpliwość, czy prawa spadkobierców koniecznych, ,jako ściśle przypisane do ich osoby”, mogą przejść na ich spadkobierców ${ }^{12}$.

${ }^{5}$ Zasadę dziedziczności roszczenia z tytułu zachowku expressis verbis przesądza art. 1002 k.c. Vide w szczególności J. Pietrzykowski, Glosa do uchwały Sądu Najwyższego z dnia 20 grudnia 1988 r., III CZP 101/88, OSP 1990, nr 4, s. 471.

${ }^{6}$ Vide np. E. Skowrońska-Bocian, J. Wierciński, Komentarz do art. 1002, [w:] Kodeks cywilny. Komentarz. Spadki, red. J. Gudowski, Warszawa 2017, teza 1.

7 Przepis art. 1002 k.c. stosuje się również do dziedziczenia roszczenia o zachowek, jeżeli uprawniony do zachowku zmarł po 31 grudnia 1964 r. Vide wyrok SN z 12 maja 1970 r., sygn. akt III CZP 26/70, Lex nr 1128.

8 Vide np. P. Księżak, Komentarz do art. 1002, [w:] Kodeks cywilny. Komentarz, t. III..., teza 4.

9 P. Księżak, Zachowek..., Warszawa 2012, s. 346 i 348; idem, Komentarz do art. 1002, [w:] Kodeks cywilny. Komentarz, t. III..., teza 2. W kontekście przepisów europejskiego rozporządzenia spadkowego warto zaznaczyć, że ograniczenia dotyczące dziedziczności konkretnych praw czy obowiązków podlegają prawu właściwemu dla tych praw czy zobowiązań. Lex causae rozstrzyga także o ich ,przynależności” z punktu widzenia składu spadku, tj. czy stanowią spadek, czy są z niego wyłączone. O dopuszczalności i zasadach dziedziczenia roszczenia z tytułu zachowku po pierwszym spadkodawcy jako jego lex causae decyduje prawo właściwe dla dziedziczenia po tym spadkodawcy. Vide szerzej M.A. Zachariasiewicz, Przepisy wymuszające swoje zastosowanie a statut spadkowy, [w:] Nowe europejskie prawo spadkowe, red. M. Pazdan, J. Górecki, Warszawa 2015, s. 329-331. Vide też M. Mataczyński, Przepisy ograniczajace dziedziczenie na tle art. 30 rozporzadzenia spadkowego, [w:] Nowe europejskie prawo spadkowe, red. M. Pazdan, J. Górecki, Warszawa 2015, s. 307-311.

10 Dz.U. nr 60, poz. 328.

11 Vide np. W. Chojnowski, Prawo spadkowe, Warszawa 1951, s. 195; A. Baziński, Prawo spadkowe. Komentarz, Łódź 1948, s. 299.

12 W. Chojnowski, Prawo..., s. 195. 
Zgodnie z jednolitym stanowiskiem judykatury i w zasadzie jednolitym stanowiskiem doktryny ${ }^{13}$ formułowanym $\mathrm{w}$ związku z ograniczeniami wskazanymi w art. 1002 k.c., wystarczającą przesłanką warunkującą dziedziczenie roszczenia o zachowek jest sama przynależność do kręgu osób uprawnionych do zachowku po pierwszym spadkodawcy. Podmiotami, na rzecz których następuje dziedziczenie roszczenia z tytułu zachowku, są osoby uprawnione do zachowku po pierwszym spadkodawcy, niezależnie od tego czy w konkretnej sytuacji faktycznej przysługiwałoby im własne prawo do zachowku po tym pierwszym spadkodawcy ${ }^{14}$. Do takiego wniosku prowadzi „,funkcjonalna wykładnia tego artykułu, odpowiadająca jego celowi społecznemu i poczuciu słuszności”"15. Pogląd przeciwny, jak podkreślają przedstawiciele doktryny, czyniłby dziedziczenie roszczenia o zachowek całkowicie iluzorycznym, bowiem zupełnie wyjątkowo może się zdarzyć, że spadkobiercy uprawnionego do zachowku przysługuje jednocześnie zachowek po pierwszym spadkodawcy. Stanie się tak np., gdy uprawniony do zachowku jeden $\mathrm{z}$ synów spadkodawcy umrze przed zaspokojeniem roszczenia $\mathrm{z}$ tego tytułu, a roszczenie to odziedziczy jego brat — również syn spadkodawcy jako uprawniony do zachowku po swoim ojcu ${ }^{16}$. Natomiast dzieci zmarkego (uprawnionego do zachowku)

${ }_{13}$ Vide np. J. Kosik, [w:] System prawa cywilnego, t. IV, Prawo spadkowe, red. J.S. Piątowski, Wrocław-Warszawa-Kraków-Gdańsk-Lódź 1986, s. 560; P. Księżak, Komentarz do art. 1002, [w:] Kodeks cywilny. Komentarz, t. III..., teza 5; J. Ciszewski, J. Knabe, Komentarz do art. 1002, [w:] Kodeks cywilny. Komentarz, red. J. Ciszewski, Warszawa 2013, tezy 2 i 9; I. Ramus, Dziedziczenie roszczenia o zachowek, [w:] Aequitas Sequitur Legem. Księga Jubileuszowa z okazji 75. urodzin Profesora Andrzeja Zielińskiego, red. K. Flaga-Gieruszyńska, G. Jędrejek, Warszawa 2014, s. 471; E. Niezbecka, Komentarz do art. 1002, [w:] Kodeks cywilny. Komentarz, t. IV, Spadki, red. A. Kidyba, Warszawa 2015, teza 2; M. Pazdan, Komentarz do art. 1002, [w:] Kodeks cywilny, t. III, Komentarz, Art. 450-1088, Przepisy wprowadzajace, red. K. Pietrzykowski, Warszawa 2015, nb 2; J. Kremis, R. Strugała, Komentarz do art. 1002, [w:] Kodeks cywilny. Komentarz, red. E. Gniewek, P. Machnikowski, Warszawa 2016, nb 1; E. Skowrońska-Bocian, J. Wierciński, Komentarz do art. 1002..., teza 2. Odmienny pogląd sformułował w ostatnim czasie T. Sokołowski, Komentarz do art. 1002, [w:] Kodeks cywilny. Komentarz, red. M. Gutowski, Warszawa 2016, teza 3. Zdaniem T. Sokołowskiego do spadkobierców dziedziczących roszczenie o zachowek należą spadkobiercy uprawnionego, którzy po nim są uprawnieni do zachowku. Trudno jednak znaleźć dla tak sformułowanego stanowiska podstawę w obowiązujących przepisach.

14 Vide w szczególności uchwały SN: z 22 grudnia 1982 r., sygn. akt III CZP 60/82, „Prawo i Życie” 1983, nr 22, s. 15; z 20 grudnia 1988 r., sygn. akt III CZP 101/88, OSP 1990, nr 4, poz. 213; także wyrok SA w Warszawie z 28 września 2018 r., sygn. akt VI ACa 754/17, Lex nr 2631475.

15 J. Pietrzykowski, Glosa do uchwaty Sadu Najwyższego z dnia 20 grudnia 1988r., III CZP $101 / 88 \ldots$.., s. 471. Taki pogląd autor wyraził już w komentarzu do kodeksu cywilnego w 1972 r. (J. Pietrzykowski, [w:] Kodeks cywilny. Komentarz, t. 3, Księga czwarta - Spadki. Przepisy wprowadzające Kodeks cywilny, red. J. Pietrzykowski, Warszawa 1972, s. 1918-199).

${ }^{16}$ Vide w szczególności J. Pietrzykowski, Glosa do uchwały Sąu Najwyższego z dnia 20 grudnia 1988 r.., s. 471 oraz B. Kordasiewicz, [w:] System prawa prywatnego, t. 10, Prawo spadkowe, red. B. Kordasiewicz, Warszawa 2015, s. 1096. Confer M. Załucki, Komentarz do art. 1002, [w:] Kodeks cywilny. Komentarz, t. VI, Spadki (art. 922-1087), red. M. Habdas, M. Fras, Warszawa 2019, teza 3. Wprawdzie Autor zaznaczył, że chodzi w tym przypadku o osoby jedynie potencjalnie uprawnione do zachowku, ale zaraz potem stwierdził, że na skutek śmierci osoby, której to roszczenie przysługiwało ,zaktualizowało się ich własne o roszczenie o zachowek". Takie stwierdzenie może budzić wątpliwości, chyba że jest to tylko pewien skrót myślowy. Rozróżnić należy bowiem dwie sytuacje: kiedy uprawniony do zachowku nabywa 
nie mogłyby odziedziczyć roszczenia $\mathrm{z}$ tytułu zachowku, ponieważ same w tym przypadku do zachowku po pierwszym spadkodawcy nie byłyby uprawnione z uwagi na to, że „wcześniej” uprawnionym jest ich ojciec ${ }^{17}$.

Powódka, w sprawie w której zapadł glosowany wyrok, wystąpiła ze skargą konstytucyjną, wnosząc o stwierdzenie niezgodności art. 1002 k.c. w zakresie, w jakim przewiduje, że roszczenie z tytułu zachowku nie przechodzi na spadkobierców osoby uprawnionej do zachowku, którzy nie należą do osób uprawnionych do zachowku po pierwszym spadkodawcy, w sytuacji gdy osoba uprawniona do zachowku, której roszczenie z tytułu zachowku przysługiwało, zmarła po wytoczeniu powództwa lub po uznaniu roszczenia na piśmie przez zobowiązanego do jego zaspokojenia $\mathrm{z}$ art. 2, art. 21 ust. 1, art. 31 ust. 3 , art. 32 ust. 1 w związku z art. 64 ust. 1 i 2 konstytucji. Powódka nie kwestionowała samych ustawowych ograniczeń w dziedziczeniu roszczenia z tytułu zachowku. Zarzuty nie dotyczyły bowiem normatywnej treści art. 1002 k.c., ale braku skutecznej egzekucji roszczenia z tytułu zachowku za życia uprawnionego wskutek nagannego zachowania zobowiązanego, sprzecznego z zasadami współżycia społecznego i dobrymi obyczajami. TK zwrócił w tym zakresie uwagę na konieczność wyraźnego rozgraniczenia problemu „,normatywnej treści zaskarżonych przepisów” i „płaszczyzny ich zastosowania w konkretnej sprawie”. Niezgodne z przepisami i zasadami współżycia społecznego postępowanie dłużnika ,nie przesądza samo przez się o niekonstytucyjności przepisu". Poza tym podkreślił, że ,jest to zarzut oparty na sposobie stosowania prawa, a ta sfera nie jest objęta kognicją Trybunału" 18 .

Jakkolwiek z uwagi na niedopuszczalność wydania wyroku w przedmiotowej sprawie TK umorzył postępowanie, a w uzasadnieniu postanowienia zwrócił uwagę na niezwykle istotne kwestie. Przede wszystkim przypomniał ${ }^{19}$ o konieczności wyraźnego rozróżnienia prawa dziedziczenia ${ }^{20}$ i prawa do zachowku, ponieważ w odróżnieniu „od prawa dziedziczenia Konstytucja nie ustanawia gwarancji dla samej instytucji zachowku, w szczególności nie nakazuje jej wprowadzenia, a więc tym bardziej nie determinuje ani jej kształtu, ani kręgu osób uprawnionych. Konstytucja nie rozstrzyga również, czy prawo do zachowku winno dotyczyć całego majątku należącego do spadkodawcy, czy też tylko niektórych składników tego majątku. Skoro ustawodawca

swoje uprawnienie i umiera, od tej, kiedy nie dożywa chwili otwarcia spadku i uprawnienie do zachowku nabywają osoby uprawnione $\mathrm{w}$ dalszej kolejności. W art. 1002 k.c. chodzi niewątpliwie o pierwszą sytuację (co autor sam później stwierdził, ibidem, teza 4).

17 J. Pietrzykowski, [w:] Kodeks cywilny. Komentarz, t. 3..., s. 1919 oraz B. Kordasiewicz, [w:] System prawa prywatnego, t. 10..., s. 1096.

${ }_{18}$ Uzasadnienie postanowienia TK z 8 czerwca 2011 r., sygn akt SK 14/10, OTK ZU 2011/5A/45.

19 Uzasadnienie wyroku TK z 31 stycznia 2001 r., sygn. akt P 4/99, OTK ZU 2001/1/5.

${ }^{20}$ Odnośnie do koncepcji konstytucyjnego prawa dziedziczenia vide w szczególności A. Mączyński, Konstytucyjne prawo dziedziczenia, [w:] Rozprawy prawnicze. Księga pamiatkowa Profesora Maksymiliana Pazdana, red. L. Ogiegło, W. Popiołek, M. Szpunar, Kraków 2005, s. 1165-1179 oraz J. Trzewik, Z rozważań nad koncepcja konstytucyjnego prawa dziedziczenia, [w:] Państwo. Konstytucja. Prawo. Księga pamiatkowa poświęcona Sędziemu Trybunatu Konstytucyjnego Profesorowi Henrykowi Ciochowi, Warszawa 2018, s. 443-470. 
może, nie naruszając Konstytucji, wyłączyć pewne prawa majątkowe spod mechanizmu dziedziczenia i wprowadzić ich szczególną sukcesję w razie śmierci osoby będącej ich podmiotem, to może także modyfikować regulację zachowku"21. Art. 21 ust. 1 oraz art. 64 ust. 1 konstytucji nie mogą stanowić podstawy do rekonstrukcji konstytucyjnego prawa podmiotowego do zachowku, ,a wywodzenie z tych przepisów takiego prawa prowadziłoby do wewnętrznej sprzeczności norm konstytucyjnych"22. Prawo do zachowku ma zatem wymiar prawa ustawowego i stanowi uzasadnione konstytucyjnie ograniczenie praw podmiotowych spadkodawcy. Chociaż „normy konstytucyjne nie gwarantują konstytucyjnego prawa podmiotowego do zachowku", na prawodawcy ciąży obowiązek stworzenia takiego rozwiązania, które w sytuacji rozrządzenia majątkiem na wypadek śmierci zabezpieczałoby ekonomicznie i prawnie te podmioty, które „pozostają w konstytucyjnie relewantnych relacjach rodzinnych ze spadkodawcą"23. Mając na względzie, że ustawodawca może, nie naruszając konstytucji, ukształtować sukcesję określonych praw majątkowych w sposób odbiegający od konstrukcji dziedziczenia, może także modyfikować regulację zachowku ${ }^{24}$.

Trybunał Konstytucyjny uznał, że przepis art. 1002 k.c. jest „elementem zwartego i spójnego pod względem legislacyjnym i aksjologicznym systemu zachowku”, a „eliminacja jednej z norm tworzących ten system mogłaby spowodować jego dezintegrację", wydaje się, że wniosek ten jest nie do końca uprawniony. Wiele argumentów przemawia jednak za uchyleniem art. 1002 k.c. Przede wszystkim niewątpliwie brak ograniczeń $\mathrm{w}$ rozporządzaniu wierzytelnością z tytułu zachowku w drodze czynności inter vivos. Poza sporem bowiem pozostaje, że uprawniony do zachowku może przenieść na inną osobę przysługującą mu z tego tytułu wierzytelność ${ }^{25}$. Wprawdzie zgłaszano wątpliwości dotyczące dopuszczalności przelewu wierzytelności z tytułu zachowku co do trzeciej negatywnej przesłanki wskazanej w art. 509 k.c., tj. właściwości zobowiązania, jednak należy uznać je za nieuzasadnione. W istocie niezbywalność wierzytelności może wynikać ze ściśle osobistego charakteru świadczenia, ale jak podkreślił Sąd Najwyższy, odwołując się do poglądów formułowanych w doktrynie, chociaż uprawnienie do zachowku ma „,silną przymieszkę rodzinnoprawną i służy urzeczywistnieniu obowiązku moralnego, jaki spadkodawca ma względem swoich

${ }^{21}$ Uzasadnienie postanowienia TK z 8 czerwca 2011 r., sygn. akt SK 14/10, OTK ZU 2011/5A/45 oraz wyroku TK z 25 lipca 2013 r., sygn. akt P 56/11, OTK ZU 2013/6A/11.

${ }^{22}$ Uzasadnienie wyroku TK z 25 lipca 2013 r., sygn. akt P 56/11, OTK ZU 2013/6A/11. Vide też uzasadnienie postanowienia TK z 23 marca 2016 r., sygn. akt Ts 296/15, OTK ZU 2016/B/277. Confer W. Borysiak, Dziedziczenie. Konstrukcja prawna i ochrona, Warszawa 2013, s. 95-96.

${ }^{23}$ Uzasadnienie postanowienia TK z 23 marca 2016 r., sygn. akt Ts 296/15, OTK ZU 2016/B/277. Vide A. Herbet, O konstytucyjności instytucji zachowku, [w:] Rozprawy cywilistyczne. Księga pamiątkowa dedykowana Profesorowi Edwardowi Drozdowi, red. M. Pecyna, J. Pisuliński, M. Podrecka, Warszawa 2013, s. 618.

${ }^{24}$ Uzasadnienie postanowienia TK z 8 czerwca 2011 r., sygn. akt SK 14/10, OTK ZU 2011/5A/45.

${ }^{25}$ Wyrok SN z 13 lutego 1975 r., sygn. akt III CZP 91/74, Lex nr 1863. Vide np. J. Pietrzykowski, Glosa do uchwaty Sadu Najwyższego z dnia 20 grudnia 1988 r., III CZP 101/88..., s. 471 oraz F. Zoll, Prawo cywilne w zarysie opracowane przy wspótudziale A. Szpunara. Prawo spadkowe, t. V, Warszawa 1948, s. 104-105. 
najbliższych" ${ }^{26}$, jednak na to przyznanie prawa do zachowku tylko wąskiemu gronu najbliższych spadkodawcy osób ,nie nadaje wierzytelności z tytułu zachowku tak dalece osobistego, aby pozbawiał on ją przymiotu prawa majątkowego, które może być przedmiotem zwykłego obrotu"27. Stanowisko przeciwne do wyłączającego zbywalność wierzytelności z tytułu zachowku wspiera ponadto argument dotyczący charakteru prawnego roszczenia z tytułu zachowku. Jak wcześniej zaznaczono, przysługuje ono uprawnionym bez względu na ich sytuację materialną i osobistą, jeżeli należny im zachowek nie został pokryty przez spadkodawcę w inny sposób, co wyłącza możliwość uznania je za roszczenie alimentacyjne sensu largo. W tym kontekście trafnie zwraca się uwagę w literaturze, że wprowadzenie warunków dziedziczenia tej wierzytelności przy braku ograniczeń co do przelewu wierzytelności z tytułu zachowku, tworzy ,aksjologiczną, rażącą wręcz niespójność systemową"28, a przyjęte „rozwiązanie ustawowe jest całkowicie niezrozumiałe" ${ }^{29}$. Ustawy zawierające normy nielogiczne, „nie mogą się mieścić w formule państwa prawa” ${ }^{30}$. W doktrynie można jednak odnotować także głosy przeciwne, nieznajdujące uzasadnienia dla nieograniczonego, z punktu widzenia podmiotowego, dziedziczenia zachowku - regulacja odmienna od obowiązującej wypaczałaby sens zachowku jako „swego rodzaju socjalnej ochrony osób bliskich spadkodawcy"31. Zwolennicy obowiązującego rozwiązania normatywnego podkreślają, że uzasadnia je ratio legis zachowku. Ograniczenie dziedziczenia roszczenia z tytułu zachowku oparto na względach natury rodzinnej, ponieważ wynika ono ze stosunku rodzinnego między spadkodawcą a uprawnionym do zachowku. Aby utrzymać tę „rodzinną podstawę” roszczenia wyłączono z kręgu uprawnionych do jego dziedziczenia spadkobierców niezwiązanych z pierwszym spadkodawcą stosunkiem rodzinnym ${ }^{32}$.

Poza sporem pozostaje, że przyjęte rozwiązanie prowadzi do nierównego traktowania spadkobierców uprawnionego do zachowku w sytuacji zastosowania przez spadkodawcę zróżnicowanych sposobów jego pokrycia. Nie zawsze „realizacja” prawa do zachowku przyjmie postać wierzytelności pieniężnej. Roszczenie o zapłatę sumy pieniężnej potrzebnej do pokrycia zachowku lub jego uzupełnienia przysługuje

${ }^{26}$ Uzasadnienie uchwały SN z 12 maja 1970 r., sygn. akt III CZP 26/70, Lex nr 1128.

27 Uzasadnienie wyroku SN z 13 lutego 1975 r., sygn. akt III CZP 91/74, Lex nr 1863.

28 P. Księżak, Zachowek..., s. 353.

29 B. Kordasiewicz, [w:] System prawa prywatnego, t. 10..., s. 1096.

${ }^{30}$ P. Księżak, Zachowek..., s. 353; idem, Komentarz do art. 1002, [w:] Kodeks cywilny. Komentarz, t. III..., teza 3 .

31 M. Załucki, Komentarz do art. 1002, [w:] Kodeks cywilny. Komentarz, t. VI..., s. 512. Te same zarzuty formułowane są co do nieograniczonej zbywalności roszenia z tytułu zachowku. Stąd zwolennicy istnienia czy też wprowadzenia w tym zakresie ograniczeń dopuszczają możliwość podniesienia zarzutu nadużycia prawa w przypadku dochodzenia zapłaty zachowku przez osoby, które nabyły wierzytelność i nie należą do kategorii osób bliskich spadkodawcy (ibidem, s. 512).

32 Vide np. J. Kosik, [w:] System prawa cywilnego, t. IV..., s. 560. Stąd wątpliwości co trafności rozwiązania przyjętego w dekrecie - Prawo spadkowe wyrażał J. Gwiazdomorski, (Prawo spadkowe, Warszawa 1959, s. 421), podnosząc, że przepis art. 158 ,nie uwzględnia w wystarczającej mierze natury prawnej praw spadkobierców koniecznych". 
uprawnionemu do zachowku tylko wówczas, gdy należnego mu zachowku nie otrzymał bądź w postaci uczynionej przez spadkodawcę darowizny, bądź w postaci powołania do spadku, bądź w postaci zapisu (art. 991 § 2 k.c.). Skoro przepis art. 1002 k.c. ogranicza dziedziczność jedynie roszczenia z tytułu zachowku, to dotyczy on jedynie takiej sytuacji, w której takie roszczenie uprawnionemu przysługuje. Oznacza to, że wartość ekonomiczna należna tytułem zachowku wejdzie w skład spadku po uprawnionym bez względu na krąg jego spadkobierców, jeśli spadkodawca wybierze jeden ze wskazanych w art. $991 \S 2$ k.c. sposobów jego pokrycia ${ }^{33}$. Okazuje się, że najmniej korzystna jest sytuacja spadkobierców uprawnionego do zachowku, który umiera przed zaspokojeniem roszczenia $\mathrm{z}$ tytułu zachowku, ewentualnie przed jego zbyciem, jeżeli nie należą oni do kręgu uprawnionych zgodnie z art. 1002 k.c. Sposób, w jaki dojdzie do zaspokojenia uprawionego do zachowku, nie powinien wpływać na zróżnicowanie sytuacji prawnej jego spadkobierców ${ }^{34}$. Pozostawienie w tym zakresie wyboru spadkodawcy w połączeniu z przyjętymi w art. 1002 k.c. zasadami dziedziczenia roszczenia z tytułu zachowku skutkuje przyznaniem pośrednio pierwszemu spadkodawcy uprawnienia do ukształtowania składu spadku po uprawnionym do zachowku.

Przyjęte rozwiązanie prowadzi ponadto do przełamania zasady jedności spadku, tj. „rozczłonkowania spadku” ${ }^{35}$ — spadek bowiem rozpada się na dwie części. W literaturze trafnie wskazuje się w tym przypadku na analogię do dziedziczenia gospodarstw rolnych $w$ okresie, kiedy obowiązywały w tym zakresie ograniczenia ${ }^{36}$. Trudno jednak nie dostrzec tu pewnej niekonsekwencji. O ile w odniesieniu do dziedziczenia gospodarstw rolnych ustawodawca ,zadbał” także o kwestie proceduralne, o tyle w przypadku roszczenia o zachowek nie zostały one unormowane ${ }^{37}$. Nie budzi bowiem wątpliwości, że wskazane w art. 1002 k.c. ograniczenia podmiotowe co do dziedziczenia mogą wpłynąć na zróżnicowanie kręgu spadkobierców — dziedziczących i nie dziedziczących roszczenia o zachowek. Oznacza to w przypadku braku stosownej regulacji ustawowej, że postanowienie sądu oraz akt poświadczenia dziedziczenia nie będzie odzwierciedlał rzeczywistego stanu prawnego. Nie trzeba przekonywać o trudnościach, jakie pojawią się chociażby w sytuacji zbycia czy działu spadku ${ }^{38}$. Jeżeli uprawniony do zachowku zostałby powołany do dziedziczenia w części odpowiadającej wysokości zachowku, zostałby ustanowiony na jego rzecz zapis zwykły czy zapis windykacyjny bądź otrzymałby darowiznę od spadkodawcy, to jego spadkobiercy znajdą się w jednakowej sytuacji, a zasada jedności spadku nie zostanie przełamana.

${ }^{33}$ Ewentualnie uprawniony do zachowku dokona przed śmiercią zbycia wierzytelności z tego tytułu.

${ }^{34}$ Tak też P. Księżak, Glosa do wyroku SN z 28 kwietnia 2010 r., III CSK 143/09, „Palestra” 2011, nr 7-8, s. 125. Vide I. Ramus, Dziedziczenie roszczenia o zachowek..., s. 466.

${ }^{35}$ P. Księżak, Zachowek..., s. 346.

${ }^{36}$ P. Księżak, Zachowek..., s. 351, a za nim W. Borysiak, Dziedziczenie..., s. 220.

${ }^{37}$ Confer art. $1029^{1}$ k.c.

${ }^{38}$ P. Księżak, Glosa do wyroku SN z 28 kwietnia 2010r., III CSK 143/09..., s. 126; idem, Zachowek..., s. 351; idem, Komentarz do art. 1002, [w:] Kodeks cywilny. Komentarz, t. III..., teza 2; W. Borysiak, Dziedziczenie..., s. 221-222. Vide też J. St. Piątowski, B. Kordasiewicz, Prawo spadkowe. Zarys wykładu, Warszawa 2003, s. 228. 
$\mathrm{Na}$ koniec jeszcze jeden argument świadczący o nieracjonalności ustawodawcy. Wydaje się bowiem, że roszczenie z tytułu zachowku, które nabyła w drodze dziedziczenia jedna z osób należących do uprawnionych do zachowku po pierwszym spadkodawcy, podlega dziedziczeniu na ogólnych zasadach, tzn. bez ograniczeń wskazanych w art. 1002 k.c. W analizowanym stanie faktycznym oznaczałoby to, że roszenie o zachowek, które przysługiwało bratu powoda i przez powoda zostało odziedziczone, nabyła jego żona ${ }^{39}$.

\section{Hanna Witczak*}

* Dr hab. Hanna Witczak, prof. Katolickiego Uniwersytetu Lubelskiego Jana Pawła II, Katedra Podstaw Prawa Cywilnego i Prawa Prywatnego Międzynarodowego, hwitczak@poczta.fm, orcid https://orcid.org/0000-0002-5949-3052

${ }^{39}$ P. Księżak, Glosa do wyroku SN z 28 kwietnia 2010 r., III CSK 143/09..., s. 126 oraz I. Ramus, Dziedziczenie roszczenia o zachowek..., s. 466. 